\title{
Plenty of prey, few predators: what limits lions Panthera leo in Katavi National Park, western Tanzania?
}

\author{
Christian Kiffiner, Britta Meyer, Michael Mühlenbergand
}

MATTHIAS WALTERT

\begin{abstract}
We present a study from Katavi National Park and surrounding areas that assessed the size and structure of the lion population as a baseline for wildlife management. We assessed lion and prey species density directly by sample surveys that incorporated specific detection probabilities. By using three prey-biomass regression models we also indirectly estimated lion density based on the assumption that these indirect estimates represent the Park's carrying capacity for lions. To identify key factors influencing lion abundance we conducted Spearman Rank correlation and logistic regression analyses, using prey species abundance and distance to Park boundary as explanatory variables. The mean size of the lion population was $31-45 \%$ of the estimated carrying capacity, with considerably fewer subadult males observed than expected. Lions generally avoided areas of up to $3 \mathrm{~km}$ from the Park boundary and were not observed outside the Park. Abundance of common prey species was significantly correlated with distance to the Park boundary and lion abundance. Lion abundance was most strongly associated with waterbuck abundance/presence. Based on observed lion demography, an evaluation of hunting quotas in adjacent hunting blocks, and anecdotal information on traditional lion hunting, we hypothesize that anthropogenic mortality of lions outside Katavi National Park is affecting lion abundance within the Park. Our results suggest that estimating lion densities with prey-biomass regression models overestimates densities even inside protected areas if these areas are subject to natural and anthropogenic edge effects.
\end{abstract}

Keywords Katavi National Park, herbivore prey, lion, Panthera leo, playback survey, Tanzania.

Christian Kiffner* (Corresponding author), Michael MüHLenberg and Matthias Waltert Department of Conservation Biology, Centre for Nature Conservation, Georg-August-Universität Göttingen, Von-SieboldStrasse 2, 37075 Göttingen, Germany. E-mail ckiffne@gwdg.de

Britta Meyer Katavi-Rukwa Conservation and Development Programme, Dar es Salaam, Tanzania.

*Also at: Department of Forest Zoology and Forest Conservation, BüsgenInstitute, Georg-August-Universität Göttingen, Göttingen, Germany.

Received 21 December 2007. Revision requested 14 March 2008.

Accepted 4 July 2008.

\section{Introduction}

The conservation status of the African lion Panthera leo 1 has been a matter of debate because lion numbers are suspected to have declined by $30-50 \%$, and recent investigations have shown that the African lion population is 23,000-39,000 (IUCN SSC Cat Specialist Group, 2006). However, many estimates of lion subpopulations are based on educated guesses (Chardonnet, 2002; Bauer \& van der Merwe, 2004; IUCN SSC Cat Specialist Group, 2006), whereas effective conservation and management require accurate estimates of population sizes.

Because carnivore density is scaled with prey biomass (Carbone \& Gittleman, 2002), it can be modelled indirectly with regression models provided that information on prey biomass is available (Gros et al., 1996). The carnivore density derived from this relationship can also be regarded as the ecological carrying capacity of the ecosystem (Hayward et al., 2007). However, this approach only works as long as no other mechanisms limit a carnivore population. For lion populations, a variety of top-down limitations have been identified. Expanding human populations often result in reduction and fragmentation of suitable habitat and increasing frequencies of human-lion conflicts (Nowell \& Jackson, 1996; Harcourt et al., 2001). Where lions and humans coexist, lions may become man eaters (Packer et al., 2005) and may kill livestock, and this often leads to destruction of lions (Woodroffe \& Frank, 2005). This anthropogenic mortality can cause local extinctions of lions even within protected areas (Woodroffe \& Ginsberg, 1998). Trophy hunting may contribute to declining lion numbers. Hunting quotas were found to be unsustainable for Game Reserves in Tanzania (Creel \& Creel, 1997; Caro et al., 1998), whereas actual offtake was considered sustainable (Creel \& Creel, 1997; Whitman et al., 2007). A case study from Zimbabwe showed that unsustainable offtake outside Hwange National Park resulted in a skewed sex structure and increased rates of infanticide after territorial males were replaced by new male coalitions inside the National Park (Loveridge et al., 2007). Epizootics can also severely affect lion populations (Kissui \& Packer, 2004).

Here we compare an indirect (estimates from three prey biomass-lion density models) with a direct method of estimating lion density, using data on the lion population of Katavi National Park, Tanzania. We directly assessed 
lion density and demography using a calibrated playback survey, a method that has been proposed for the assessment of lion population size (Ogutu \& Dublin, 1998). We hypothesized that the three indirect density estimates would be higher than the estimate from the direct method, that anthropogenic and ecological factors may be responsible, and that these could be observed through edge effects.

\section{Study area}

We conducted this study in and around Katavi National Park in the Rukwa Region of western Tanzania. With an area of 4,279 $\mathrm{km}^{2}$, Katavi is Tanzania's third largest National Park. It is situated almost exclusively within the Rukwa valley, at $800-1,100 \mathrm{~m}$ altitude, and receives a mean annual rainfall of $923 \mathrm{~mm}$ in a unimodal pattern (TANAPA/WD, 2004). Katavi National Park was gazetted in 1974 to protect two seasonal lakes that support high mammal densities during the dry season (Caro, 1999a). Apart from seasonal floodplains, the Park consists mainly of Miombo woodland-dry forest (Banda et al., 2006). The Park is surrounded by Kisi and Nkamba Forest Reserves to the west, Msaginia Forest Reserve and Mlele Game Controlled Area to the north, Rukwa Game Reserve to the east and south, Lwafi Game Reserve to the south-west, and Open Areas to the south.

Hunting is not allowed inside Katavi National Park but illegal hunting of herbivores occurs (Caro, 1999c). In Rukwa and Lwafi Game Reserves and Mlele Game Controlled Area tourist hunting of male lions is allowed and restricted to an annual quota of 29 lions (20,5 and 4 lions, respectively; TANAPA/WD, 2004). Although requested by CK, information regarding lion offtake was not provided by the Wildlife Division. In other areas adjacent to the Park lion hunting is not allowed but members of the Sukuma tribe are suspected to kill lions for traditional purposes (J. Balozi, pers. comm.).

\section{Methods}

To obtain data on available prey biomass we used line transect methodology (Buckland et al., 2001) for assessing density of large herbivores in the year previous (AugustSeptember 2004) to the lion survey. With protected area staff we counted large mammals on foot along closed triangular shaped transects that were distributed systematically on a $9 \times 9 \mathrm{~km}$ grid (with a random start point) over the study area (Fig. 1). For more details see Waltert et al. (2008).

In October and November 2005 we conducted 13 calibration experiments to estimate the range and probability of lion responses to a playback sound (Mills et al., 2001). Between 18.30 and 22.00 we played a distress call of a buffalo with the speakers facing in the direction of a known number of lions. The vehicle with the audio equipment was parked a known distance (measured by a global positioning system) from the lions, and a second set of observers, in radio contact with the playback team, observed the lions. If the lions did not start moving towards the direction of the sound after a broadcast period of 5 minutes, we reduced the distance between the speakers and the lions in 200-500 $\mathrm{m}$ steps and repeated the procedure. When the lions moved towards the sound we recorded this as a response. For comparing response rates among different studies, we calculated effective area equivalents $(\hat{A})$ according to Whitman et al. (2006):

$$
\hat{A}=r^{2} \times p i \times \hat{\pi}
$$

where $r$ is the response range and $\hat{\pi}$ the average response probability.

We surveyed lion abundance in the dry season months of August-November 2005. We used a standardized playback protocol (using the same sound as in the calibration experiment) to attract lions (Kiffner et al., 2008). We recorded number of incoming lions and determined their sex. We visually estimated their age by direct observation and with the help of photographs. Size (Smuts et al., 1980) and nose colouration (Whitman et al., 2004) were used as criteria for grouping lions into age classes, according to Schaller (1972). The calling stations were placed in the centres of the transects used for the prey species survey in the previous year. A second playback survey was conducted on the major roads along the border of $(n=9)$, inside $(n=14)$ and outside $(n=7)$ the Park. Calling stations for the road survey were $8 \mathrm{~km}$ apart and the first station was placed randomly. No playbacks were performed in proximity to known settlements (Fig. 1).

We modelled lion population size with a probability based model (Mills et al., 2001) in Mathematica v. 5.0 (Wolfram Research, Champaign, USA). We estimated the expected number of responding lions $(\hat{\mu})$ within the response range by

$$
\hat{\mu}=\bar{y} / \hat{\pi}
$$

where $\bar{y}$ is the mean number of lions responding per station and $\hat{\pi}$ the probability that lions approach the calling station. We directly observed $\bar{y}$ during the survey and estimated $\hat{\pi}$ with the calibration experiments. These experiments also provided information on response range, i.e. the radius of the circle in which lions were effectively lured. The population size was then calculated using the relation

$$
N_{\mathrm{T}}=\left(A_{\mathrm{T}} / A_{\mathrm{S}}\right) \times \hat{\mu}
$$

where $N_{\mathrm{T}}$ is the population size of lions in Katavi National Park, $A_{\mathrm{T}}$ the total area of the Park, $A_{\mathrm{S}}$ the circular area around a calling station, and $\hat{\mu}$ the expected number of lions per station (Mills et al., 2001). Small lion cubs did not 


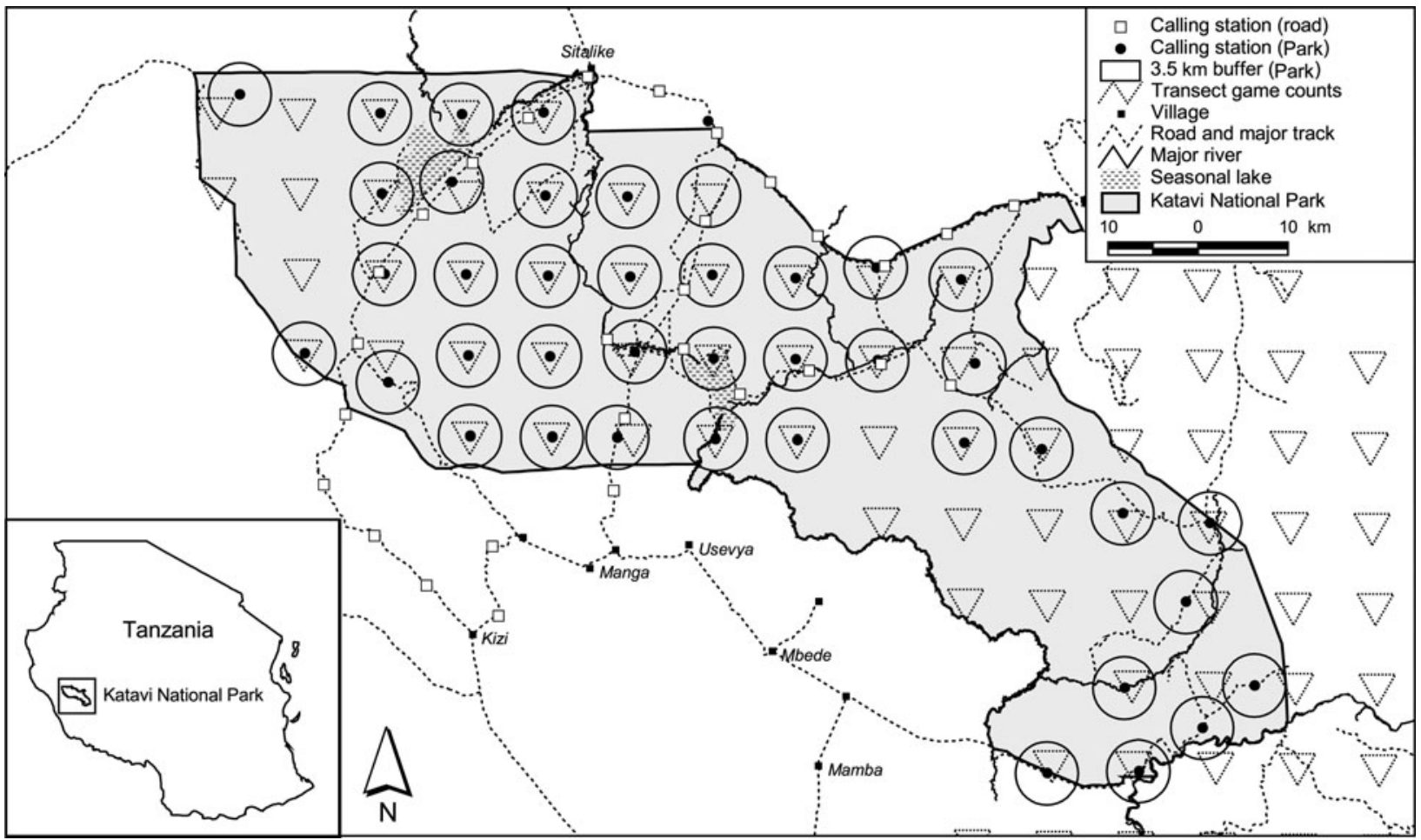

FIG. 1 The study area, showing the locations of all calling stations of the lion survey in 2005 and the triangular transects used for the prey species survey in 2004.

respond to the playback (Ogutu \& Dublin, 1998) and hence population estimates excluded lions $<1$ year old.

We used three regression models that relate prey biomass and lion density to estimate the ecological carrying capacity of the ecosystem for lions. The models were derived by pooling published data of prey biomass and lion density from different areas of southern and eastern Africa, and differed in the species considered to be prey. Model 1 was derived from Carbone \& Gittleman (2002) and Harvey (2004), who considered all large herbivores as potential prey species: $\ln ($ lion density) $=-6.81243+0.05652 * \ln$ (prey biomass), $\mathrm{R}^{2}=0.54, \mathrm{P}<0.0001$. Model 2 is from Hemson (2003), who excluded elephants, hippopotamus and giraffe as potential prey species: $\log ($ lion density $)=-1.69216+$ $0.80916{ }^{*} \log$ (prey biomass), $\mathrm{R}^{2}=0.80, \mathrm{P}<0.0001$. Model 3 is based on preferred and avoided prey species of lions in southern and eastern Africa (Hayward \& Kerley, 2005), for which Hayward et al. (2007) proposed a model restricted to preferred prey species (Table 1): $\log ($ lion density) $=-2.158+$ $0.377^{*} \log$ (preferred prey biomass), $\mathrm{R}^{2}=0.626, \mathrm{P}<0.001$.

We used Spearman Rank tests to detect correlations between lion abundance, prey species abundance and distance to the nearest Park boundary. Distances were measured in the geographical information system ArcView v. 3.2 (ESRI, Redlands, USA). To investigate whether lion response was influenced by local abundance of potential prey species we correlated numbers of attracted lions with numbers of herbivores encountered in the previous year.
We assumed that the distribution and relative abundance of herbivores was the same in both years. We also assumed that we came across herbivore species in the same manner as lions do; hence we used numbers of encountered individuals as proxies for local abundance of potential prey species. Logistic regression models were used to identify variables influencing lion response during the response experiment and during the survey. We used SPSS v. 15 (SPSS, Illinois, USA) for statistical analyses.

\section{Results}

In the prey species survey impala, zebra, topi and buffalo had the highest densities (Table 1). We estimated total herbivore biomass density at $6,339 \mathrm{~kg} \mathrm{~km}^{-2}$ with elephant, hippopotamus and giraffe contributing $64 \%$ of the biomass of larger herbivores. Removing these species yielded a mean biomass estimate of $2,307 \mathrm{~kg} \mathrm{~km}^{-2}$. The biomass of preferred lion prey species (Table 1) was estimated to be $2,056 \mathrm{~kg} \mathrm{~km}^{-2}$.

In the calibration experiment 24 of 39 tested lions responded to the playback sound, with a response probability of $0.62 \pm$ SE 0.14 (Table 2). Lions either responded as a group or not at all, leading to a large standard error. The lions only responded from a distance of $\leq 3.5 \mathrm{~km}$. A multiple logistic regression suggested using an average response probability. Neither distance between speakers and lions, tending of cubs, previous exposure to playback or possession of a carcass had a significant effect (all P-values $>0.05$ ) on 
TABLE 1 Estimates of mean densities and coefficient of variation of density (CV) of large mammalian herbivores in Katavi National Park. Mean biomass density was derived from average female body weight multiplied by 0.75 * mean density.

\begin{tabular}{|c|c|c|c|}
\hline Species & $\begin{array}{l}\text { Mean } \\
\text { density } \\
\left(\mathrm{km}^{-2}\right)\end{array}$ & $\mathrm{CV}$ & $\begin{array}{l}\text { Mean biomass } \\
\text { density } \\
\left(\mathrm{kg} \mathrm{km}^{-2}\right)\end{array}$ \\
\hline Impala Aepyceros melampus ${ }^{\mathrm{A}}$ & 5.02 & 0.43 & 181 \\
\hline Zebra Equinus burchelli ${ }^{\mathrm{P}}$ & 4.00 & 0.45 & 660 \\
\hline Topi Damaliscus lunatus ${ }^{\mathrm{C}}$ & 3.15 & 0.57 & 255 \\
\hline Buffalo Syncerus caffer ${ }^{\mathrm{P}}$ & 2.04 & 0.50 & 881 \\
\hline Hippopotamus & 1.33 & & 1,379 \\
\hline \multicolumn{4}{|l|}{ Hippopotamus amphibius ${ }^{\mathrm{C}}$} \\
\hline $\begin{array}{l}\text { Warthog Phacochoerus } \\
\text { africanus } \mathrm{C}\end{array}$ & 1.31 & 0.25 & 64 \\
\hline Giraffe Giraffa camelopardalis ${ }^{\mathrm{P}}$ & 0.98 & 0.24 & 515 \\
\hline Duiker Sylvicapra grimmia ${ }^{\mathrm{A}}$ & 0.96 & 0.27 & 12 \\
\hline Elephant Loxodonta africana ${ }^{\mathrm{A}}$ & 0.95 & 0.43 & 2,138 \\
\hline Reedbuck Redunca spp. ${ }^{\mathrm{A}}$ & 0.74 & 0.53 & 25 \\
\hline $\begin{array}{l}\text { Waterbuck Kobus } \\
\text { ellipsiprymnus } \mathrm{C}\end{array}$ & 0.40 & 0.51 & 56 \\
\hline Small antelope $\mathrm{e}^{\star \mathrm{A}}$ & 0.37 & 0.36 & 3 \\
\hline $\begin{array}{l}\text { Bushbuck Tragelaphus } \\
\text { scriptus }^{\mathrm{A}}\end{array}$ & 0.33 & 0.33 & 11 \\
\hline Eland Taurotragus oryx ${ }^{\mathrm{C}}$ & 0.32 & 0.53 & 94 \\
\hline Kongoni Alcelaphus buselaphus ${ }^{\mathrm{C}}$ & 0.26 & 0.69 & 25 \\
\hline $\begin{array}{l}\text { Bush pig Potamochoerus } \\
\text { larvatus } \mathrm{C}\end{array}$ & 0.21 & 0.67 & 11 \\
\hline $\begin{array}{l}\text { Roan antelope Hippotragus } \\
\text { equinus }{ }^{\mathrm{C}}\end{array}$ & 0.15 & 0.53 & 29 \\
\hline Total & & & 6,339 \\
\hline
\end{tabular}

*Small antelope may include duiker Sylvicapra grimmia, Sharpe's grysbok Raphicerus sharpei, steenbuck Raphicerus campestris and oribi Ourebia ourebi

${ }^{\mathrm{A}}$ Avoided prey species; ${ }^{\mathrm{C}}$ Common prey species; ${ }^{\mathrm{P}}$ Preferred prey species (Hayward \& Kerley, 2005).

response probability. However, for estimating mean response probability, we excluded the four experiments with lions that had already been exposed to the sound. We thus estimated that lions within $3.5 \mathrm{~km}$ of the calling station responded with a probability of $0.68 \pm \mathrm{SE} 0.18$, which is equivalent to responding within an area of $26.2 \mathrm{~km}^{2}$.

During the lion survey we recorded a total of 42 lions at $11(26.8 \%)$ of the 41 stations. The number of attracted lions ranged from $0-15$ with a mean of $1.02 \pm$ SD 2.68 lions per station. Incorporating response range and extrapolating resulted in an estimate of $168(77-439)$ lions or a density of $0.04(0.02-0.10)$ lions $\mathrm{km}^{-2}$. During playbacks along roads, we observed 29 lions at six (20\%) out of 30 calling stations. Along the border two lions were observed at one out of nine (11\%) calling stations, giving a mean of $0.22 \pm$ SD 0.67 lions per station. Within Katavi National Park, lions were observed at five out of 14 stations (36\%), with $0-11$ lions and a mean of $1.93 \pm$ SD 3.6 lions per station. In the areas south of Katavi National Park (Lwafi Game Reserve and
TABLE 2 Number of approaching lions when the sound was played from a known distance to a known number of lions. Lions tested multiple times are indicated ${ }^{\mathrm{a}, \mathrm{b}}$.

\begin{tabular}{lll}
\hline & $\begin{array}{l}\text { No. } \\
\text { played to }\end{array}$ & $\begin{array}{l}\text { No. } \\
\text { responding }\end{array}$ \\
\hline 3.5 & 3 & 3 \\
$3.5,3.3,3.1,2.9,2.7,2.5,2.0,1.5,1.0,0.5$ & $1^{\mathrm{a}}$ & 0 \\
$3.9,3.5,3.3,3.1,2.9,2.5,2.0,1.5,1.0,0.5$ & $2^{\mathrm{a}}$ & 0 \\
0.8 & 2 & 2 \\
1.5 & 1 & 1 \\
$3.7,3.5,3.3,3.1,2.9,2.7,2.5,2.0,1.5$, & 3 & 0 \\
$1.0,0.5$ & & \\
3.5 & 5 & 5 \\
0.5 & 4 & 0 \\
0.4 & $2^{\mathrm{b}}$ & 2 \\
3.5 & 11 & 11 \\
3.5 & 1 & 0 \\
2.3 & 1 & 0 \\
1.8 & $3^{\mathrm{a}}$ & 0 \\
Total & 39 & 24 \\
\hline
\end{tabular}

Open Areas) we neither observed nor heard lions at seven calling stations.

Based on the biomass density of all large herbivores estimated lion density corresponded to $25 \%$ (range 12-66\%) of the predicted carrying capacity (Model 1a). To correct the population estimate for the non-responding small cubs, we added the share of small cubs in a reference area $(22 \%$, Maasai Mara: Ogutu \& Dublin, 2002) to the estimate (Model $1 \mathrm{~b}$ ), accounting for $31 \%(14-81 \%)$ of the carrying capacity. The second model, which excluded most megaherbivores indicated that the directly estimated lion density corresponded to $36 \%$ (17-96\%; Model 2a) and 45\% (21-117\%; Model $2 \mathrm{~b}$ ) of the predicted carrying capacity. The model that only considered preferred prey species accounted for $32 \%$ (15-84\%; Model 3a) or 39\% (18-102\%; Model $3 \mathrm{~b})$ of the predicted carrying capacity (Table 3 ).

Number of responding lions was significantly correlated with the distance between calling station and the Park boundary (Spearman Rank correlation coefficient $r=0.355$, $\mathrm{P}=0.002, \mathrm{n}=72$ ), thus indicating higher lion densities in core areas of the Park (Fig. 2). With the exclusion of playbacks outside the Park there was still a significant correlation between distance to the Park boundary and number of lions $(r=0.299, \mathrm{P}=0.016, \mathrm{n}=64)$. Similarly, abundance of all herbivores was significantly correlated with distance to the boundary, although at a species level this was significant for topi only (Table 4 ). Number of responding lions was not correlated with overall abundance of herbivores. However, number of responding lions was associated with local abundance of waterbuck. Numbers of responding lions were not correlated with abundance of their preferred prey species (buffalo, giraffe and zebra) but significantly more lions responded in areas with high local 
TABLE 3 Indirect vs direct lion density estimates in Katavi National Park. The indirect density was estimated by using the relationship between prey biomass density (using data from the 2004 dry season herbivore count) and lion density. The direct estimate was derived from the playback census carried out in the dry season of 2005 .

\begin{tabular}{|c|c|c|c|}
\hline Model $^{\mathrm{ab}}$ & $\begin{array}{l}\text { Indirect } \\
\text { density } \\
\text { estimate } \\
\left(\mathrm{km}^{-2}\right)\end{array}$ & $\begin{array}{l}\text { Direct } \\
\text { density } \\
\text { estimate } \\
\text { (range), } \mathrm{km}^{-2}\end{array}$ & $\begin{array}{l}\text { Difference } \\
\text { (direct-indirect } \\
\text { density estimate) } \\
\text { (range), } \mathrm{km}^{-2}\end{array}$ \\
\hline$\overline{1 a^{1}}$ & 0.155 & $0.039(0.018-0.103)$ & $-0.116(-0.137--0.052)$ \\
\hline $1 b^{1}$ & 0.155 & $0.048(0.022-0.125)$ & $-0.107(-0.133--0.029)$ \\
\hline $2 a^{2}$ & 0.107 & $0.039(0.018-0.103)$ & $-0.068(-0.089--0.004)$ \\
\hline $2 b^{2}$ & 0.107 & $0.048(0.022-0.125)$ & $-0.059(-0.085-+0.019)$ \\
\hline $3 a^{3}$ & 0.123 & $0.039(0.018-0.103)$ & $-0.084(-0.105--0.020)$ \\
\hline $3 b^{3}$ & 0.123 & $0.048(0.022-0.125)$ & $-0.076(-0.101-+0.002)$ \\
\hline
\end{tabular}

${ }^{\mathrm{ab}}$ Model a, lion density excluding small cubs; Model b, including small cubs (share of small cubs estimated at 22\%; Ogutu \& Dublin, 2002)

${ }^{1}$ Based on Harvey (2004), included all large herbivore species

${ }^{2}$ Based on Hemson (2003), excluded elephant, hippopotamus and giraffe

${ }^{3}$ Based on Hayward et al. (2007), included buffalo, giraffe and zebra only

abundance of common prey species. This group of herbivores (eland, waterbuck, roan, bushpig, warthog, topi and hippopotamus) also significantly avoided edge areas of the Park (Table 4).

In a logistic regression (stepwise backward elimination of insignificant variables), distance to boundary (Wald $\left.\chi^{2}=2.697, \mathrm{df}=1, \mathrm{P}=0.101\right)$ and abundance of common prey species (Wald $\chi^{2}=3.990, \mathrm{df}=2, \mathrm{P}=0.136$ ) were rejected as explanatory variables for the presence of lions. Presence of waterbuck was a significant variable (Wald $\left.\chi^{2}=7.165, \mathrm{df}=1, \mathrm{P}=0.007\right)$. The validity of the model was verified by the significance of the likelihood quotient $\left(\chi^{2}=7.91, \mathrm{df}=1, \mathrm{P}=0.005\right.$, Omnibus test of model coefficients). The model explained $18.4 \%$ (Cox \& Snell $\mathrm{R}^{2}$ ) or $26.4 \%$ (Nagelkerke's $\mathrm{R}^{2}$ ) of the variance.

Overall, the sex ratio of the sampled lions in the Park did not differ from that of a total count in Maasai Mara Reserve, Kenya $\left(\chi^{2}=0.069, \mathrm{df}=1, \mathrm{P}=0.792\right)$, although in the sample in Katavi National Park considerably fewer

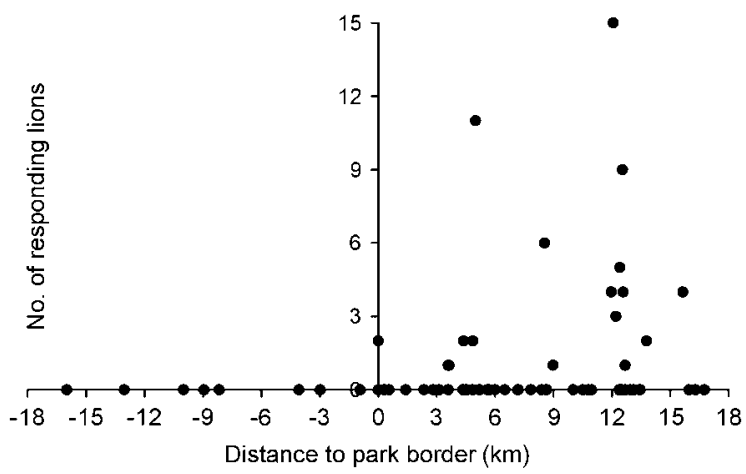

FIG. 2 Number of lions responding to the playback sound in relation to distance to the border of Katavi National Park. Negative values on the $\mathrm{x}$-axis indicate locations outside the Park.
TABLE 4 Spearman Rank correlations between number of encountered herbivores in 2004 and responding lions in 2005 and between number of encountered herbivores and distance to Park boundary from the centre of each sample plot. For all correlations $\mathrm{n}=39$.

\begin{tabular}{|c|c|c|c|c|}
\hline \multirow[b]{2}{*}{ Species } & \multicolumn{2}{|c|}{ Herbivores-lions } & \multicolumn{2}{|c|}{$\begin{array}{l}\text { Herbivores-distance } \\
\text { to boundary }\end{array}$} \\
\hline & $\mathrm{r}$ & $\mathrm{P}^{1}$ & $\mathrm{r}$ & $\mathrm{P}^{1}$ \\
\hline Elephant & 0.02 & 0.95 & 0.24 & 0.14 \\
\hline Hippopotamus & 0.30 & 0.06 & 0.28 & 0.08 \\
\hline Giraffe & -0.10 & 0.53 & -0.22 & 0.17 \\
\hline Buffalo & 0.01 & 0.95 & 0.16 & 0.34 \\
\hline Large-sized herbivores & -0.03 & 0.85 & 0.17 & 0.29 \\
\hline Eland & 0.31 & 0.06 & 0.05 & 0.79 \\
\hline Roan antelope & 0.16 & 0.33 & -0.07 & 0.69 \\
\hline Zebra & 0.06 & 0.70 & 0.09 & 0.61 \\
\hline Waterbuck & 0.56 & $<0.01$ & 0.13 & 0.42 \\
\hline Kongoni & 0.05 & 0.77 & -0.17 & 0.29 \\
\hline Topi & -0.08 & 0.64 & 0.46 & $<0.01$ \\
\hline Medium-sized herbivores & 0.23 & 0.16 & 0.30 & 0.07 \\
\hline Bushpig & 0.30 & 0.06 & 0.12 & 0.47 \\
\hline Warthog & 0.02 & 0.89 & 0.05 & 0.76 \\
\hline Impala & 0.18 & 0.27 & 0.23 & 0.17 \\
\hline Reedbuck & -0.09 & 0.61 & 0.07 & 0.66 \\
\hline Bushbuck & 0.22 & 0.18 & -0.03 & 0.86 \\
\hline Small antelope ${ }^{2}$ & 0.19 & 0.16 & -0.07 & 0.67 \\
\hline Small-sized herbivores & 0.30 & 0.06 & 0.23 & 0.16 \\
\hline All herbivores & 0.24 & 0.14 & 0.36 & 0.02 \\
\hline Preferred prey species ${ }^{3}$ & 0.02 & 0.92 & 0.05 & 0.78 \\
\hline Common prey species $^{3}$ & 0.42 & $<0.01$ & 0.39 & 0.01 \\
\hline $\begin{array}{l}\text { Preferred \& common } \\
\text { prey species }{ }^{3}\end{array}$ & 0.22 & 0.18 & 0.26 & 0.12 \\
\hline
\end{tabular}

${ }^{1}$ Significant values $(\mathrm{P}<0.05)$ in italics

${ }^{2}$ Small antelope may include duiker Sylvicapra grimmia, Sharpe's grysbok Raphicerus sharpei, steenbuck Raphicerus campestris and oribi Ourebia ourebi

${ }^{3}$ See Table 1

subadult males were observed $\left(\chi^{2}=4.840, \mathrm{df}=1, \mathrm{P}=\right.$ 0.0278 ) than in Maasai Mara (Table 5).

\section{Discussion}

The direct lion density estimate was considerably lower than the carrying capacity of Katavi National Park for lions predicted using the three prey-biomass models (Table 3). This may indicate the presence of a top-down factor limiting the population (Carbone \& Gittleman, 2002). One potential reason for this difference could be that the survey was biased. However, although we were not able to conduct playbacks at 15 of the designated sampling stations because of inaccessibility we believe it was appropriate to extrapolate to the entire area because we sampled $37 \%$ of the Park. Ogutu \& Dublin (1998) demonstrated that sampling $20 \%$ of an area yielded unbiased estimates for lions. In addition, we estimated population density of both prey species and lions 
TABLE 5 Population structure of responding lions during the systematic playback survey carried out in Katavi National Park over August-November 2005 and, for comparison, in Maasai Mara Reserve Kenya (Ogutu \& Dublin, 2002).

\begin{tabular}{|c|c|c|c|c|c|c|}
\hline \multirow[b]{2}{*}{ Age } & \multicolumn{3}{|c|}{ Katavi National Park } & \multicolumn{3}{|c|}{$\underline{\text { Maasai Mara, Kenya }}$} \\
\hline & Female & Male & $\begin{array}{c}\text { Sex ratio } \\
(F: M)\end{array}$ & Female & Male & $\begin{array}{c}\text { Sex ratio } \\
(F: M)\end{array}$ \\
\hline Large cubs & 3 & 6 & $0.5: 1$ & 23 & 36 & $0.6: 1$ \\
\hline Subadults & 9 & 3 & $3: 1$ & 32 & 46 & $0.7: 1$ \\
\hline $\begin{array}{l}\text { Adults } \\
>4 \text { yrs }\end{array}$ & 11 & 5 & $2.2: 1$ & 213 & 97 & $2.2: 1$ \\
\hline Unknown & 5 & & $1.6: 1$ & & & $1.5: 1$ \\
\hline Total & 42 & & & 447 & & \\
\hline
\end{tabular}

with methods incorporating specific detection probabilities (Karanth et al., 2004), and response of lions is neither biased by time of the night, moon phase or presence of spotted hyaenas (Kiffner et al., 2008).

Another potential reason for the discrepancy between the survey and regression model estimates could be a biased detection probability calibration. However, although Whitman et al. (2006) found that response of lions to spotted hyaena calls was biased by sex, age, presence of males and cubs, position of calling station relative to territory and group size, and that response probability declines with increasing distance between lions and speakers, our analysis did not show significant effects of the tested variables. The number of calibration experiments in our study was comparably low and hence the probability of committing a type II error (i.e. that there was an effect but it did not reach statistical significance) is high. We were not able to conduct more response experiments because we did not find previously untested lions in 3 additional days of intensive searches with two observer teams. However, the area equivalent of lion response $\left(26.2 \mathrm{~km}^{2}\right)$ was similar to response experiments with the same sound and comparable audio equipment in Krüger National Park $\left(33.3 \mathrm{~km}^{2}\right.$; Funston et al., 2007). Nevertheless, we recommend conducting more playback experiments, as done by Whitman et al. (2006).

Because we can exclude low prey availability as a factor limiting lions inside Katavi National Park there must be other factors limiting this lion population. Although the prey species survey was carried out in the previous year we are confident that abundance and local distribution of prey species did not differ markedly because there was similar surface water and vegetation distribution in both years. Competition with spotted hyaenas could be one limiting factor. Their numbers were estimated to be $741 \quad(95 \%$ confidence limits 580-954; Kiffner, 2006) thus outnumbering lions by a factor of 4.4. This numerical superiority enables spotted hyaenas to drive lions from their kills in the absence of a male lion (Cooper, 1991). We cannot rule out effects of diseases on lions in Katavi National Park, although we have no specific information on this issue. However, no observations indicative of disease have previously been made by protected area staff or researchers and disease is regarded as minor threat for this subpopulation (IUCN SSC Cat Specialist Group, 2006).

Lions were less abundant at stations near the boundary of Katavi National Park and were not detected outside. Ogutu et al. (2005) proposed two, not necessarily exclusive, reasons for this: either non-detection indicates lower abundance or absence, or lions are present but respond with a lower probability. Caro (2005) showed that large mammals exposed to hunting pressure outside Katavi National Park are significantly more wary, and this could result in them not approaching the playback sound. However, lions are commonly hunted on foot and during daylight and thus waryness is unlikely to explain non responses to playbacks broadcasted exclusively at night and from a vehicle. Whitman et al. (2006) conducted playback surveys in areas where lions were being hunted and observed 0.19-1.77 lions per station. Even though we used a more effective playback sound (hyaena calls used by Whitman et al., 2006, produced lower area equivalents: $11 \mathrm{~km}^{2}$ and $19 \mathrm{~km}^{2}$ for female and male lions) only two lionesses responded on the boundary and none south of the Park. In addition, neither direct counts (Caro, 1999c) nor indirect spoor surveys detected lions in areas adjacent to the Park (Caro, 2003). Lions were reported to be observed in these areas (Caro, 2003) but because several methods failed to detect them, we conclude this is strong evidence that lion densities are low outside the Park.

An avoidance of less protected areas and edge areas of Katavi National Park by lions could be due to both natural and anthropogenic factors. Partly, this effect could be explained by lower prey species densities outside the Park. Katavi National Park was delineated according to high densities of umbrella species (Caro, 2003) and overall wildlife abundance and consequently lion abundance should be lower outside the Park. Yet, lion abundance was not closely tied to prey species abundance, thus suggesting this parameter does not influence lion distribution per se. Presence of waterbuck, a species closely associated with presence of surface water (Stuart \& Stuart, 2001) was a predictor for lion presence. This association was probably incidental, because waterbuck is not a preferred prey species (Hayward \& Kerley, 2005). Hopcraft et al. (2003) showed that lions feed mainly in areas with high prey 'catchability' rather than high prey density, and such locations (with features such as erosion embankments, rocky outcrops and access to surface water) are also preferred by waterbuck. Caro (2005) showed that waterbuck are significantly less abundant in areas outside Katavi National Park, possibly because of inadequate habitat, and thus low abundance of lions there could be at least partly attributed to low availability of suitable habitat.

Caro et al. (1998) suspected that trophy hunting of lions was unsustainable in Katavi National Park. Hunting quotas in adjacent areas amounted to 29 male individuals per 
hunting season (TANAPA/WD, 2004). We estimated that in the Park there were c. 16 (range 7-42) male lions above the recommended age for trophy lions (Whitman et al., 2004). Given that large herbivore biomass in Rukwa Game Reserve is c. $40 \%$ of the larger herbivore biomass of Katavi National Park (Waltert et al., 2008), the lion population in the Reserve was presumably significantly lower than in the Park. Hence, hunting quotas (Rukwa Game Reserve: 20 male lions) allowed unsustainable harvest of lions. This assumption is supported by the slightly skewed sex ratio, which could be interpreted as indication of an impact of selective, male-biased harvesting (Milner et al., 2007). Caro (1999b) found a similar sex ratio among sub-adult and adult lions in Katavi National Park ( 0.27 males per females vs $0.20-0.40$ in this study) but a differing sex ratio among cubs (0.32 vs 1.5-2.0). The observed sex ratio indicates that either mortality or emigration (or both) of young male lions is high. We hypothesize that this mortality may be caused by trophy and traditional hunting, eliminating young migrating lions outside the Park.

Our hypotheses were not rejected. The indirect estimates overestimated the lion population, suggesting that the lion population of Katavi National Park is below its ecological carrying capacity. Our results provide evidence that ecological factors (lower prey abundance, possibly less access to surface water) outside the Park contribute to the observed edge effects. Hunting of lions by humans in adjacent areas may be responsible for a skewed sex ratio and low abundance of lions in edge areas and outside the Park. To minimize negative effects on lion demography and abundance, offtake of trophy lions in Tanzania is now restricted to male lions with a minimum age of 6 years (Whitman et al., 2004; 2007). Compliance with this policy needs to be strictly controlled and the success of this hunting regulation should be measured by additional direct estimates of lion demography and abundance.

Overall, our study suggests that carnivore density derived from prey biomass equations should be interpreted cautiously, even for protected areas if these areas are subject to natural and anthropogenic edge effects, thus highlighting the need for direct assessments of lion density.

\section{Acknowledgements}

We acknowledge Tanzania National Parks and the Tanzanian Wildlife Division for their efforts in wildlife population assessment. We thank Hubert Krischke (GTZ/ ECO-AGEG) for financial support. Thanks to the Katavi National Park garage staff, to the field crew L. Kinyonto, P. Mgangala, R. Simbamwene, G. Maronda and M. Mgangala, and P. Funston for providing the playback file. We thank C. Blum and C. Staley for help with the manuscript, and T. Caro, P. Funston, L. Hunter, C. Kleinn, M. Kiffner, G. Mills,
C. Packer, F. Rühe, K. Whitman, W. Zucchini and two anonymous referees for advice and comments.

\section{References}

Banda, T., Schwartz, M.W. \& CARo, T. (2006) Woody vegetation structure and composition along a protection gradient in a miombo ecosystem of western Tanzania. Forest Ecology and Management, 230, 179-185.

Bauer, H. \& van Der Merwe, S. (2004) Inventory of free-ranging lions Panthera leo in Africa. Oryx, 38, 26-31.

Buckland, S.T., Anderson, D.R., Burnham, K.P., LaAke, J.L., Borchers, D.L. \& Thomas, L. (eds) (2001) Introduction to Distance Sampling. Estimating Abundance of Biological Populations. Oxford University Press, Oxford, UK.

Carbone, C. \& Gittleman, J.L. (2002) A common rule for the scaling of carnivore density. Science, 295, 2273-2276.

Caro, T.M. (1999a) Abundance and distribution of mammals in Katavi National Park, Tanzania. African Journal of Ecology, 37, 305-313.

CARo, T.M. (1999b) Demography and behaviour of African mammals subject to exploitation. Biological Conservation, 91, 91-97.

Caro, T.M. (1999c) Densities of mammals in partially protected areas: the Katavi ecosystem of western Tanzania. Journal of Applied Ecology, 36, 205-217.

Caro, T.M. (2003) Umbrella species: critique and lessons from East Africa. Animal Conservation, 6, 171-181.

CAro, T.M. (2005) Behavioural indicators of exploitation. Ethology, Ecology \& Evolution, 17, 189-194.

Caro, T.M., Pelkey, N., Borner, M., Severre, E.L.M., Campbell, K.L.I., Huish, S.A. et al. (1998) The impact of tourist hunting on large mammals in Tanzania: an initial assessment. African Journal of Ecology, 36, 321-346.

Chardonnet, P. (ed.) (2002) Conservation of the African Lion: Contribution to a Status Survey. International Foundation for the Conservation of Wildlife, Paris, France \& Conservation Force, Metairie, USA.

Cooper, S.M. (1991) Optimal hunting group size: the need for lions to defend their kills against loss to spotted hyaenas. African Journal of Ecology, 29, 130-136.

Creel, S. \& Creel, N.M. (1997) Lion density and population structure in the Selous Game Reserve: evaluation of hunting quotas and offtake. African Journal of Ecology, 35, 83-93.

Funston, P.J., Ferreira, S.M., Snyman, A. \& de Beer, H. (2007) Assessment of lion population demography and abundance in the Kruger National Park: calibration and survey of the north. African Lion News, 7, 16-18.

Gros, P.M., Kelly, M.J. \& Caro, T.M. (1996) Estimating carnivore population densities for conservation purposes: indirect methods compared to baseline demographic data. Oikos, 77, 197-206.

Harcourt, A.H., Parks, S.A. \& Woodroffe, R. (2001) Human density as an influence on species/area relationships: double jeopardy for small African reserves? Biodiversity and Conservation, 10, 1011-1026.

Harvey, A. (2004) Determinants of carnivore density. MSc thesis, Imperial College London, London, UK.

Hayward, M.W. \& Kerley, G.I.H. (2005) Prey preferences of the lion (Panthera leo). Journal of Zoology, 267, 309-322.

Hayward, M.W., O’Brien, J. \& Kerley, G.I.H. (2007) Carrying capacity of large African predators: predictions and tests. Biological Conservation, 139, 219-229.

Hemson, G. (2003) The ecology and conservation of lions: humanwildlife conflict in semi-arid Botswana. $\mathrm{PhD}$ thesis, University of Oxford, Oxford, UK. 
Hopcraft, J.G.C., Sinclair, A.R.E. \& Packer, C. (2005) Planning for success: Serengeti lions seek prey accessibility rather than abundance. Journal of Animal Ecology, 74, 559-566.

IUCN SSC Cat Specialist Group (2006) Regional Conservation Strategy for the Lion Panthera leo in Eastern and Southern Africa. IUCN SSC Cat Specialist Group, Gland, Switzerland [http:// www.catsg.org/catsgportal/bulletinboard/o5_strategies/Lion\%20Conserv\%20Strat\%20E\&S\%20Africa\%202006.pdf, accessed 28 March 2008].

Karanth, K.U., Nichols, J.D., Kumar, N.S., Link, W.A. \& Hines, J.E. (2004) Tigers and their prey: predicting carnivore densities from prey abundance. Proceedings of the National Academy of Sciences of the USA, 101, 4854-4858.

KiffNer, C. (2006) The use of a playback survey to estimate African lion (Panthera leo) and spotted hyaena (Crocuta crocuta) densities: methodological aspects and implications for the management of lions. MSc thesis, Georg-August University, Göttingen, Germany.

Kiffner, C., Waltert, M., Meyer, B. \& Mühlenberg, M. (2008) Response of lions (Panthera leo Linnaeus 1758) and spotted hyaenas (Crocuta crocuta Erxleben 1777) to sound playbacks. African Journal of Ecology, 46, 223-226.

Kissui, B. \& PACKer, C. (2004) Top down population regulation of a top predator: lions in the Ngorongoro Crater. Proceedings of the Royal Society B, 271, 1867-1874.

Loveridge, A.J., Searle, A.W., Murindagomo, F. \& Macdonald, D.W. (2007) The impact of sport-hunting on the population dynamics of an African lion population in a protected area. Biological Conservation, 134, 548-558.

Mills, M.G.L., Juritz, J.M. \& Zucchini, W. (2001) Estimating the size of spotted hyaena (Crocuta crocuta) populations through playback recordings allowing for non response. Animal Conservation, 4, 335-343.

Milner, J.M., Nilsen, E.B. \& Andreassen, H.P. (2007) Demographic side effects of selective hunting in ungulates and carnivores. Conservation Biology, 21, 36-47.

Nowell, K. \& Jackson, P. (eds) (1996) Wild Cats. Status Survey and Conservation Action Plan. IUCN/SSC Cat Specialist Group, Gland, Switzerland.

Ogutu, J.O., Bhola, N. \& Reid, R. (2005) The effects of pastoralism and protection on the density and distribution of carnivores and their prey in the Mara ecosystem of Kenya. Journal of Zoology, 265, 281-293.

Ogutu, J.O. \& Dublin, H. (1998) The response of lions and spotted hyaenas to sound playbacks as a technique for estimating population size. African Journal of Ecology, 36, 83-95.

Ogutu, J.O. \& Dublin, H. (2002) Demography of lions in relation to prey and habitat in the Maasai Mara National Reserve, Kenya. African Journal of Ecology, 40, 120-129.

Packer, C., Ikanda, D., Kissui, B. \& Kushnir, H. (2005) Lion attacks on humans in Tanzania. Nature, 436, 927-928.

Schaller, G.B. (1972) The Serengeti Lion: A Study of Predator Prey Relations. The University of Chicago Press, Chicago, USA.
Smuts, G.L., Robinson, G.A. \& Whyte, I.J. (1980) Comparative growth of wild male and female lions (Panthera leo). Journal of Zoology, 190, 365-373.

Stuart, C. \& Stuart, T. (2001) Field Guide to the Larger Mammals of Africa. Struik Publisher, Cape Town, South Africa.

TANAPA/WD [Tanzania National Parks/Wildlife Division] (2004) Katavi-Rukwa-Lukwati Ecosystem Management Plan. Unpublished report. Tanzania National Parks/ Department of Planning and Projects Development Wildlife Divison, Arusha, Tanzania.

Waltert, M., Meyer, B., Shanyangi, M.W., Balozi, J.J., Kitwara, O., Qolli, S. et al. (2008) Foot surveys of large mammals in woodlands of western Tanzania. Journal of Wildlife Management, 72, 603-610.

Whitman, K.L., Durant, S.M., Maddox, T.M., Laake, J.L. \& PACKER, C. (2006) The limitations of using spotted hyaena callins to estimate lion population size. In Modelling, Monitoring \& The Sustainable Use of Lion Populations in Tanzania (ed. K.L. Whitman), pp. 97-148. PhD thesis, University of Minnesota, St Paul, USA.

Whitman, K.L., Starfield, A.M., Quadling, H.S. \& PaCker, C. (2004) Sustainable trophy hunting of African lions. Nature, 428, 175-178.

Whitman, K.L., Starfield, A.M., Quadling, H. \& Packer, C. (2007) Modelling the effects of trophy selection and environmental disturbance on a simulated population of African lions. Conservation Biology, 21, 591-601.

Woodroffe, R. \& Ginsberg, J.R. (1998) Edge effects and the extinction of populations inside protected areas. Science, 280, 2126-2128.

Woodroffe, R. \& Frank, L.G. (2005) Lethal control of African lions (Panthera leo): local and regional population impacts. Animal Conservation, 8, 91-98.

\section{Biographical sketches}

Christian Kiffner studied the distribution and abundance of large carnivores and herbivores in the Katavi ecosystem using innovative and non-invasive methods. His research is now focused on understanding the ecology and dynamics of tick and rodent borne diseases in Germany. BRITta Meyer planned and implemented the ecological monitoring programme for the Katavi-Rukwa-Ecosystem. Michael Mühlenberg's research focuses on conservation strategies in the tropics and the boreal zone and on international nature conservation. Matthias Waltert is working on the impacts of deforestation and land use on tropical biodiversity. He worked on improving wildlife population assessments in West and East Africa and coordinates an interdisciplinary research project linking wildlife management and livelihoods in Cameroon and Nigeria. 